\title{
Developmental pattern of esterases in Apis mellifera $L$ honey bees. I. Stage-dependent changes of esterase isoenzymes in Africanized workers
}

\author{
VLC Figueiredo, ZL Paulino-Simões, MMG Bitondi
}

\author{
Universidade de São Paulo, Faculdade de Filosofia, Ciências e Letras de Ribeirão Preto, \\ Departamento de Biologia, Av Bandeirantes, 3900, 14040-901 Ribeirão Preto, SP, Brazil
}

(Received 22 June 1995; accepted 19 January 1996)

\begin{abstract}
Summary - The esterases of Africanized Apis mellifera worker honey bees were investigated during pre- and postimaginal development. Embryos, larvae, pupae and adults of different ages were examined. The phenotypic variation detected by electrophoresis on Penetrose 30 gels was stage specific. This variation permitted us to classify seven distinct esterase phenotypes for workers: one for embryos, two for the larval phase, one for prepupae and non-pigmented pupae, one for pupae in the process of pigmentation, one for the final pupal stage and for young adults, and one for adults older than $72 \mathrm{~h}$. This study showed that these esterase phenotypes, in addition to representing markers of specific stages of ontogenetic development, are alternated at the beginning of critical events such as eclosion, larvapupa transition, cuticle pigmentation and adult emergence.
\end{abstract}

esterase / development / Apis mellifera / Africanized honey bee

\section{INTRODUCTION}

Protein and enzyme characterization in honey bees, Apis mellifera L, has mainly emphasized studies of polymorphism. However, some authors have also studied the variation in the number and activity of isozymes, particularly esterase isozymes, during the different periods of bee life (Tripathi and Dixon, 1968; Nunamaker and Wilson, 1982; Bitondi and Mestriner 1983; Krieg and Mareck, 1983; Ruvolo-Takasusuki, 1994). Nevertheless, only some developmental phases have been examined and the onset and period of activity of each esterase isoenzyme have not been determined. The specific objective of the present study was to undertake a detailed investigation of the qualitative variations of esterase isozymes during the ontogenetic development of $A$ mellifera, by characterizing the electrophoretic patterns peculiar to the embryo, the different larval instars, 
pupae and adults, to determine the developmental times characterized by the onset, persistence and loss of activity of the different esterase isozymes.

\section{MATERIAL AND METHODS}

\section{Apis mellifera (Africanized honey bees)}

Bees were captured in nature in the State of São Paulo, Brazil, and maintained in the Department of Genetics of the Faculty of Medicine of Ribeirão Preto, University of São Paulo. Periodically, each of the three queens used was imprisoned for a period of $6 \mathrm{~h}$ on a comb free of brood. The limitation of the oviposition period guaranteed age uniformity $(0-6 \mathrm{~h})$ of the samples. Workers in different phases of preimaginal development, as defined by Michelette and Soares (1993), and some newly emerged adults were collected for the electrophoretic analysis. Other newly emerged adults were immediately marked on the thorax and reintroduced into their colonies of origin to be recollected and analyzed at different days of adult life.

\section{Sample preparation for electrophoretic analysis}

Samples for electrophoretic analysis of esterases were collected daily at $24 \mathrm{~h}$ intervals starting from oviposition. Larvae in the feeding stage were washed with $0.02 \mathrm{M}$ Tris- $\mathrm{HCl}$ buffer, $\mathrm{pH} 7.5$, to remove food adhering to the epidermis. The digestive tract was extracted from samples in feeding stages to avoid sample contamination. The number of bees per sample and the volume of buffer used in the homogenization process were chosen according to bee size: pools of 200 embryos, 200 first instar larvae (L1), 50 second instar larvae (L2) or five third instar larvae (L3) were homogenized in $30 \mu \mathrm{L} 0.02 \mathrm{M}$ Tris- $\mathrm{HCl}, \mathrm{pH}$ 7.5. The remaining larval phases, pupae and adults were analyzed individually: each fourth instar larva ( $\mathrm{L} 4$ ) was homogenized in $90 \mu \mathrm{L}$ of the same buffer and each fifth instar larva (L5), pupa or adult in $200 \mu \mathrm{l}$. Homogenates were centrifuged at $12400 \mathrm{~g}$ for $20 \mathrm{~min}$ at $5^{\circ} \mathrm{C}$ and the supernatant was absorbed by Whatman No 3 fil- ter paper $(5 \times 6 \mathrm{~mm})$ which was inserted into the starch gel for electrophoretic analysis. The analysis was performed on ten samples of embryos, L1, L2 and L3 larvae, and on 100 samples of each of the following developmental phases: larval instars (L4, L5), prepupae aged 138-144 (PP1), 162-168 (PP2) and 186-192 h (PP3) postoviposition, pupae differing in the extent of eye pigmentation $\mathrm{Pw}, \mathrm{Pp}, \mathrm{Pdp}$ and $\mathrm{Pb}$ (white-, pink-, dark pink- and brown-eyed pupae, respectively), brown-eyed pupae differing in the extent of cuticle pigmentation $\mathrm{Pbl}, \mathrm{Pbm}$, Pbd (light, medium and dark-pigmented cuticles, respectively), and adults aged from $0-6 \mathrm{~h}$ to 35 days ( $\mathrm{A} 1$ to $A 35$ ).

\section{Starch gel electrophoresis}

Esterase phenotypes were obtained by the method of Bitondi and Mestriner (1983) but using an alternative support (kindly provided by Refinações de Milho do Brasil, Ltda) known as Penetrose 30 , a maize amyloid of 23000 molecular weight, pH 4.8 to 5.9 (previously tested by Val et al, 1981, for some protein systems). The gels were prepared at $10 \%$ in $0.02 \mathrm{M}$ Tris- $\mathrm{HCl}$ buffer, $\mathrm{pH} 7.5$. Esterase migration occurred for $4-5 \mathrm{~h}$ at $7^{\circ} \mathrm{C}$, at $5 \mathrm{~V} / \mathrm{cm}$. The buffer used in the electrode compartments was $0.3 \mathrm{M}$ Tris- $\mathrm{HCl}, \mathrm{pH} 7.5$.

\section{Esterase detection}

Esterase bands were detected using 4-methylumbelliferyl acetate or butyrate as substrates, poured on the internal surfaces of the horizontally cut gels (Bitondi and Mestriner, 1983).

\section{RESULTS}

Embryos, larvae of different ages, pupae and immature and mature adults have distinct isoenzymic patterns, shown in figure 1, where shaded horizontal bars represent the activity of each esterase isozyme. The variation in isoenzymatic activity during development permitted us to enumerate seven distinct esterase phenotypes: (1) embryonic phenotype characterized by Est- 


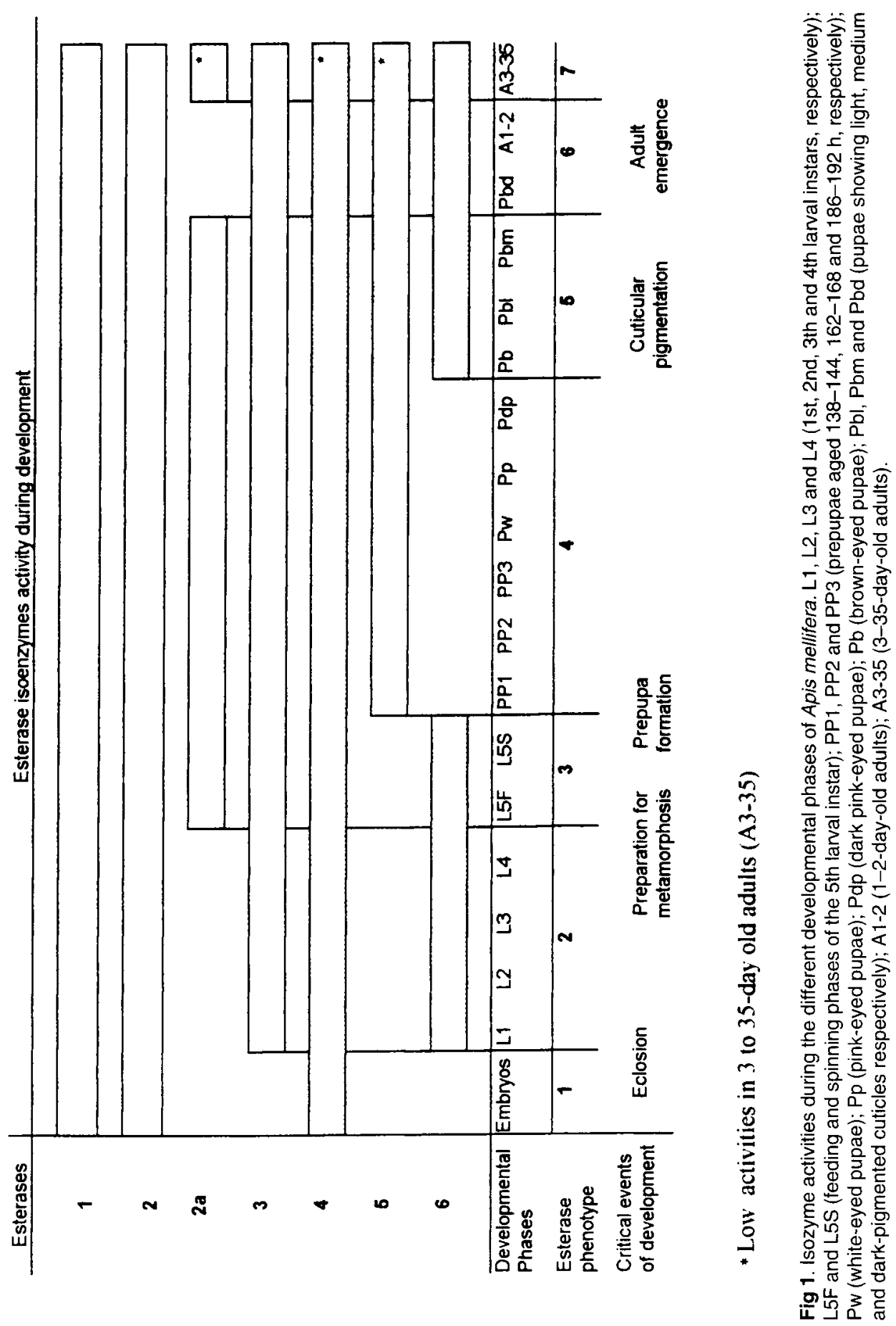


1, 2 and 4 activities (fig 2A, B: samples 1-3); (2) young larval phenotype typical of $L 1$ to L4 larvae, where two other esterases, Est3 and Est-6, were detected in addition to the embryonic esterases (fig 2A, B: samples 4-7); (3) phenotype of L5 larvae characterized by the onset of Est-2a activity occurring simultaneously with the beginning of the feeding period of the fifth instar (fig 2A, B: sample 8; fig 3A, B: sample 1); (4) phenotype of prepupae and young pupae marked not only by the appearance of a new band of enzyme activity, the Est-5, but also by the absence of Est- 6 (fig 3A, B: samples 2-7), which, previously active during larval phases, was not detected again until the end of the Pdp period; (5) phenotype of pupae in the process of cuticular pigmentation (fig 3A, B: samples 8-10); (6) phenotype typical of emerging pupae and young adults (1-2 days) characterized by the absence of Est-2a activity (fig 3A, B: samples 11,12$)$; and ( 7 ) adult phenotype, identified by the activities of all esterases, but showing characteristically low activities of Est-2a, Est-4 and Est-5.

These results clearly show a correlation between the change in phenotype and the occurrence of critical events of development. As illustrated in figure 1 , eclosion is characterized by the onset of Est-3 and Est6 activities. The beginning of the fifth larval instar (L5F) coincides with the onset of Est$2 \mathrm{a}$ activity. Both events, the onset of Est-5 activity and the lack of Est- 6 activity, are markers of prepupa formation. Cuticular pigmentation coincides with the reappearance of Est-6. Emergence occurs during a period characterized by the interruption of Est-2a activity, which is again detected immediately after the beginning of adult life.

\section{DISCUSSION}

Our study revealed that particular sets of esterase isozymes characterize the various developmental phases of $A$ mellifera workers. The seven esterase sets or phenotypes described here represent markers of the phases of development, so that critical events such as larval eclosion, cocoon spinning and larva-prepupa transition, cuticular pigmentation, and finally, emergence, are marked by alternation between the esterase phenotypes. Variation in the activity of specific enzymes or the isoenzyme ensemble unique to different phases of development reflects the gene activation and repression typically occurring in this process and suggests a role of some of the isoenzymes in characteristic events of development.

The onset and persistence of the activity of a given enzyme during a developmental period can indicate participation in specific physiological processes which occur during this period of time. For example, the $\mathrm{JH}$ esterase is active just when a decline in $\mathrm{JH}$ titre in the haemolymph is observed (Hanzlik et al, 1989; Hammock et al, 1990), which characterizes the larva-pupa transition. Hence, identification of the activity period as well as characterization of the events that are intrinsic to the period should contribute to a better knowledge of the function of a given enzyme. It is interesting to note that the Est-2a is detected for the first time in L5F when, according to Rembold (1987) and Rachinsky et al (1990), an abrupt fall in juvenile hormone levels occurs in the haemolymph. Furthermore, neither Est-2a or Est-5 are detected during the larval phases characterized by high juvenile hormone levels. While it is still impossible to determine the function of each esterase isozyme, some of them may have a determinant function in developmental stages characterized by hormonal changes, as is the case, for example, for the larva-pupa transition, characterized by the onset of Est-2a and Est-5 activities.

In the present study, the controlled ovipositions, with the queen confined for $6 \mathrm{~h}$ (so that the difference in age among her descen- 
A

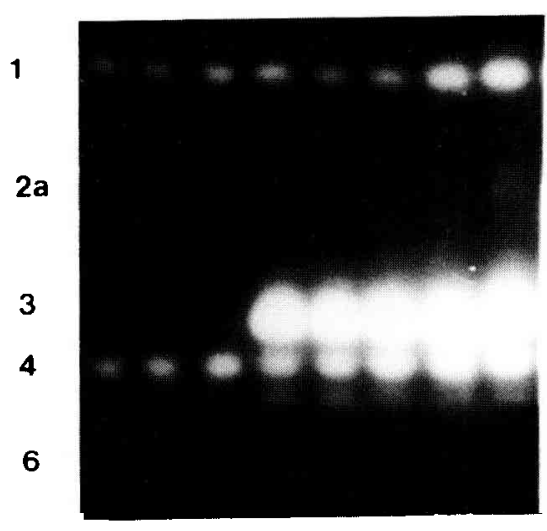

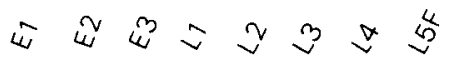

B

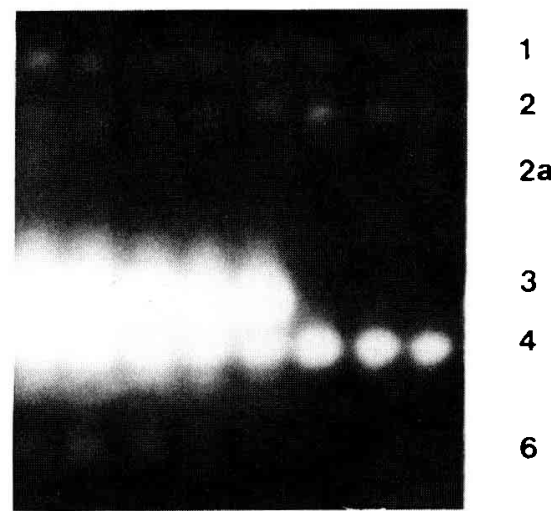

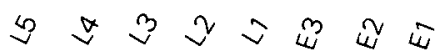

Fig 2. Esterases of Africanized Apis mellifera worker honey bees visualized on a penetrose gel after electrophoresis of total extracts and incubation of the gel with 4-methylumbelliferyl acetate $(A)$ or butyrate (B). E1, E2 and E3: embryos aged $0-6,18-24$ and $42-48 \mathrm{~h}$, respectively; $L 1, L 2, L 3$ and L4: 1st, 2nd, 3rd and 4th larval instars respectively; L5F: feeding phase of the 5th larval instar.
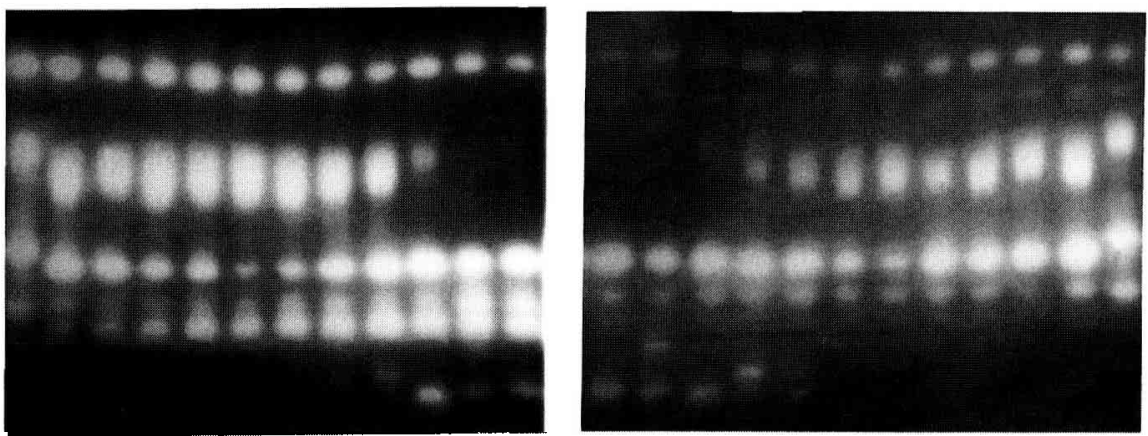

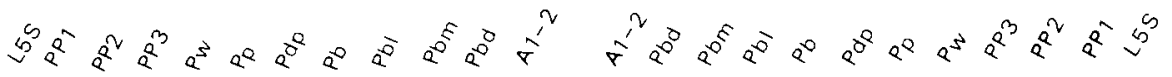

Fig 3. Esterases of Africanized Apis mellifera worker honey bees visualized on a penetrose gel after electrophoresis of total extracts and incubation of the gel with 4-methylumbelliferyl acetate (A) or butyrate (B). L5S (spinning phase of the 5th larval instar); PP1, PP2 and PP3 (prepupae aged 138-144, 162-168 and 186-192 h respectively); Pw (white-eyed pupae); Pp (pink-eyed pupae); Pdp (dark pinkeyed pupae); $\mathrm{Pb}$ (brown-eyed pupae); $\mathrm{Pbl}, \mathrm{Pbm}$ and $\mathrm{Pbd}$ (pupae showing light, medium and darkpigmented cuticles respectively); A1-2 (1-2-day-old adults). 
dants did not exceed this period of time), and the electrophoretic analysis performed during each phase permitted us to determine accurately the onset and period(s) of activity of each of the seven esterase isoenzymes during development, as indicated in figure 1. Two other esterases of $A$ mellifera were described by Ruvolo-Takasusuki and Del Lama (1991) and Ruvolo-Takasusuki et al (1993): Est-Z (subsequently named Est1a) and Est-7. Est-1a was detected in digestive tract extracts in the developed ovaries of queenless workers and embryos. The fact that Est-1a was not found in our study may be explained by the removal of the digestive tract during sample preparation to prevent extract contamination with the intestinal content. We also used workers of queenright colonies, which therefore had no developed ovaries, a fact that prevented the possible detection of ovarian Est-1a. However, in a parallel analysis conducted with queens (Figueiredo, 1993) we observed the existence of this esterase. The probable explanation for the lack of detection of embryonic Est-1a is that this esterase is more specific for 4-methylumbelliferyl propionate, which was used by the previous authors. Est-7 was occasionally visualized as a very faint band under the electrophoretic conditions we used. According to RuvoloTakasusuki (1994), this esterase is better visualized in extracts of adult head and thorax obtained with 2-phenoxyethanol.

In summary, our study showed that important events of development are marked by alterations in the esterase pattern of $A$ mellifera. Larval eclosion, the transition from larva to pupa, cuticular pigmentation and adult emergence are signaled by the onset or loss of specific isoenzyme activities (Est-2a, Est-3, Est-5 and Est-6), which define seven patterns of esterase activity during development and suggest a distinct function for each of these isoenzymes in the developmental process. Particularly interesting is the onset of activity of Est-2a and Est-5 that seems to coincide with the decline in the $\mathrm{JH}$ titre, as reported by Rembold and Hagenguth (1981), Rembold (1987) and Rachinsky et al (1990). The use of compounds potentially capable of inhibiting specifically these enzymes could help to establish their function in vivo.

\section{ACKNOWLEDGMENTS}

We thank JJ dos Santos for technical assistance. This research was supported by CNPq and CAPES.

Résumé - Profil des estérases au cours du développement chez l'abeille (Apis mellifera L). I. Variation des isozymes d'estérase en fonction du stade chez l'ouvrière africanisée. Une étude détaillée a été faite des variations des isozymes d'estérase au cours de l'ontogenèse des ouvrières d'abeilles Apis mellifera africanisées. Les profils électrophorétiques des estérases des embryons, des larves, des nymphes et des adultes ont été déterminés. Le début et la durée d'activité de chaque isozyme ont également été relevés et mis en relation avec les changements critiques survenant dans le processus de développement. Afin d'obtenir des ouvrières d'âge connu, trois reines ont été encagées avec des rayons pendant des périodes de 6 heures. Les ouvrières prélevées aux diverses phases du développement ont été broyées dans du Tris- $\mathrm{HCl}$ à $0,02 \mathrm{M}, \mathrm{pH} 7,5$, et soumises à une électrophorèse sur gel d'amidon à $10 \%$ préparé avec le même tampon. L'estérase a migré pendant $4-5$ heures à $7^{\circ} \mathrm{C}$, à $5 \mathrm{~V} / \mathrm{cm}$. Le tampon utilisé de migration était du Tris- $\mathrm{HCl}$ à $0,3 \mathrm{M}, \mathrm{pH} 7,5$. Les bandes d'estérase ont été détectées en lumière UV après incubation du gel dans une solution d'acétate ou de butyrate de 4-méthylumbelliféryle. Les variations de l'activité isozymique détectées par électrophorèse nous permettent de distinguer sept phénotypes d'estérase (figs 1-3): i) le phénotype embryonnaire, qui a le plus 
petit nombre d'estérases (Est-1, Est-2, Est-4); ii) le phénotype des jeunes larves (stades L1, L2, L3, L4) avec cinq estérases (Est-1, Est-2, Est-3, Est-4, Est-6); iii) le phénotype des larves L5, caractérisé par l'activité de 6 estérases (Est-1, Est-2, Est-2a, Est-3, Est4, Est-6); iv) le phénotype des prénymphes (PP1, PP2 et PP3) et des nymphes aux yeux blancs, roses et rose foncé ( $\mathrm{Pw}, \mathrm{Pp}, \mathrm{Pdp}$ ) avec six estérases (Est-1, Est-2, Est-2a, Est3, Est-4, Est-5); v) le phénotype des nymphes aux yeux bruns (cuticule blanche, cuticule légèrement et moyennement pigmentée: $\mathrm{Pb}$, $\mathrm{Pbl}, \mathrm{Pbm})$, caractérisé par l'activité de sept estérases (Est-1, Est-2, Est-2a, Est-3, Est4, Est-5, Est-6); vi) le phénotype des nymphes aux yeux bruns et à la cuticule fortement pigmentée ( $\mathrm{Pbd}$ ) et des adultes âgés de 1 et 2 jours (A1-A2) avec six estérases (Est-1, Est-2, Est-3, Est-4, Est-5, Est-6) et vii) le phénotype des adultes (A3-A35), caractéristique des ouvrières âgées de 3 à 35 jours, avec sept estérases (Est-1, Est-2, Est2a, Est-3, Est-4, Est-5, Est-6), bien que trois d'entre elles, Est-2a, Est-4 et Est-5, présentent une faible activité. Ces résultats montrent que les changements de l'activité isozymique sont liés aux divers stades de développement. Comme le montre la figure 1, le début de l'activité d'Est-3 et Est-6 suit l'éclosion. Le début de l'activité d'Est-2a coïncide avec le début du $5^{\mathrm{e}}$ stade larvaire. Les prénymphes se forment au moment où Est5 est détecté, moment qui coïncide aussi avec l'absence d'activité d'Est-6. L'émergence a lieu durant une période caractérisée par l'interruption de l'activité d'Est-2a, qui reprend juste après le début de la vie adulte. Les phénotypes d'estérases décrits ici sont donc des marqueurs des phases de développement, puisque celles-ci se caractérisent par des groupements particuliers d'isozymes. Ceci laisse supposer pour ces derniers l'existence d'un rôle dans les événements critiques de l'ontogenèse.

abeille africanisée / estérase / ontogenèse / polymorphisme biochimique
Zusammenfassung - Das Entwicklungsmuster von Esterasen bei Honigbienen (Apis mellifera). I. Abhängigkeit von Esterase-Isoenzymen von dem Entwicklungstadium bei afrikanisierten Arbeiterinnen. Die qualitative Variation der Zusammensetzung von Esteraseisoenzymen während der ontogenetischen Entwicklung von afrikanisierten Apis mellifera Arbeiterinnen wurde genau erfaßt. Hierbei wurden die elektrophoretischen Muster der Esterasen von Embryos, Larven, Puppen und adulten Tieren charakterisiert. Weiter wurde Anfang und Dauer der Aktivität jedes Isoenzyms festgestellt und zu kritischen Übergangsperioden des Entwicklungsprozesses in Beziehung gesetzt. Um Arbeiterinnen bekannten Alters zu erhalten, wurden drei Königinnen jeweils 6 Stunden lang auf den Waben gekäfigt. Arbeiterinnen der unterschiedlichen Entwicklungsstadien wurden in 0,02 M Tris- $\mathrm{HCl}, \mathrm{pH} 7,5$ homogenisiert und einer mit dem gleichen Puffer zubereiteten 10-prozentigen StärkegelElektrophorese unterworfen. Die Esterase wanderte bei $7^{\circ} \mathrm{C}$ und $5 \mathrm{~V} / \mathrm{cm}$ über $4-5$ Stunden. In den Elektrodenkammern wurde ein 0,3 M Tris- $\mathrm{HCl}, \mathrm{pH}$ 7,5 Puffer benutzt. Die Esterasebanden wurden nach Inkubation des Gels in einer 4-Methylumbelliferylazetat oder - butyrat unter UV-Beleuchtung sichtbar. Die hierdurch ermittelten Änderungen der Isoenzymaktivität erlaubten sieben Esterase-phänotypen deutlich $z u$ unterscheiden (Abb 1, 2, 3): 1) den embryonische Phänotyp mit der geringsten Anzahl von Esterasen (Est-1, Est-2 Est-4); 2) den Phänotyp junger Larven (L1 bis L4) mit fünf Esterasen (Est-1, Est-2, Est-3, Est4,Est-6); 3) den durch sechs aktive Esterasen gekennzeichnete larvalen Phänotyp der L5-Larven (Est-1, Est-2, Est-2a, Est-3, Est4, Est-6); 4) den das praepupale Stadium (PP1, PP2, PP3) sowie Puppen mit weißen, rosa und dunkelrosa Augen ( $\mathrm{Pw}, \mathrm{Pp}, \mathrm{Pdp}$ ) umfassenden Phänotyp mit sechs Esterasen (Est-1, Est-2, Est-2a, Est-3, Est-4, Est5); 5) den braunäugigen pupalen Phänotyp 
(weiße bis hell oder mittelstark pigmentierte Cuticula: $\mathrm{Pb}, \mathrm{Pbl}, \mathrm{Pbm}$ ), charakterisiert durch die Aktivität von sieben Esterasen (Est-1, Est-2, Est-2a, Est-3, Est-4, Est-5, Est-6); 6) den braunäugige Puppen mit dunkelgefärbter Cuticula (Pbd) zusammen mit 1-2 Tage alten Adulten (A1-2) umfassenden Phänotyp mit sechs Esterasen (Est-1, Est-2, Est-3, Est-4, Est-5, Est-6); und 7) den adulten Phänotyp (A3-35), der 3-35 Tage alte Arbeiterinnen umfaßt und durch 7 Esterasen charakterisiert wird (Est-1, Est2, Est-2a, Est-3, Est-4, Est-5, Est-6. Drei dieser Esterasen, Est-2a, Est-4 und Est-5, zeigten allerdings nur geringe Aktivität). Diese Ergebnisse belegen, daß mit den verschiedenen Entwicklungsstadien unterschiedliche Isoenzymaktivitäten verbunden sind. Wie in Abbildung 1 dargestellt, beginnt die Aktivität von Est-3 und Est-6 nach dem Schlupf der Larven. Est-2a tritt ab dem fünften Larvenstadium auf. Est-5 wird ab der Zeit der Ausbildung der Prepupa gemessen, dieser Entwicklungsabschnitt ist durch das Fehlen einer Est-6-Aktivität gekennzeichnet. Während des Schlupfs der Arbeiterinnen ist die Est-2a-Aktivität unterbrochen, die dann unmittelbar nach dem Beginn des Erwachsenenlebens wiederkehrt. Da die unterschiedlichen Phasen durch spezifische Sets von Isoenzymen gekennzeichnet werden, sind die hier beschriebenen Esterase-Phänotypen damit Marker für die Entwicklungsphasen. Dies weist darauf hin, daß einige dieser Enzyme in kritischen Entwicklungsvorgängen eine Rolle spielen könnten.

\section{Esterase / Entwicklung / Apis mellifera / afrikanisierte Honigbiene}

\section{REFERENCES}

Bitondi MMG, Mestriner MA (1983) Esterase isozymes of Apis mellifera: substrate and inhibition characteristics, developmental ontogeny, and electrophoretic variability. Biochem Genet 21, 985-1002
Figueiredo VLC (1993) Efeitos do composto organofosforado 0,0 - Dimetil - 0 - (2,2 - Diclorovinil) Fosfato (DDVP) sobre o desenvolvimento de operárias africanizadas (Apis mellifera). PhD Thesis, Faculdade de Medicina de Ribeirão Preto, Universidade de Sāo Paulo, Brazil

Hammock BD, Bonning BC, Possee RD, Hanzlik TN, Maeda $S$ (1990) Expression and effects of the juvenile hormone esterase in a baculovirus vector. Nature $344,458-461$

Hanzlik TN, Abdel-Aal YAI, Harshman LG, Hammock BD (1989) Isolation and sequencing of CDNA clones coding for juvenile hormone esterase from Heliothis virescens. J Biol Chem 21, 12419-12425

Krieg P, Marek M (1983) Protein and esterase changes in the haemolymph of the queens of honey bee, Apis mellifera L. Comp Biochem Physiol 75 B, 513

Michelette, ERD, Soares AEE (1993) Characterization of preimaginal developmental stages in Africanized honey bee workers (Apis mellifera L). Apidologie, 24, 431-440

Nunamaker RA, Wilson WT (1982) Isozyme changes in honey bee, Apis mellifera $\mathrm{L}$, during larval morphogenesis. Insect Biochem 12, 99-104

Rachinsky A, Strambi C, Strambi A, Hartfelder K (1990) Caste and metamorphosis: hemolymph titers of juvenile hormone and ecdysteroids in last instar honey bee larvae. Gen Comp Endocrinol 79, 31-38

Rembold $\mathrm{H}$ (1987) Caste specific modulation of juvenile hormone titers in Apis mellifera. Insect Biochem 17, $1003-1006$

Rembold $H$, Hagenguth $H$ (1981) Modulation of hormone pools during post-embrionic development of female honey bee castes. In: Regulation of Insect Development and Behavior (F Schnal, A Zabza, لJ Menn, B Cymbonowsk, eds), Tech Univ Press, Wrzolaw, 427-440

Ruvolo-Takasusuki MCC (1994) Caracterização genética de uma esterase sexo-especifica de Apis mellifera. PhD Thesis, Universidade Federal de Säo Carlos, $\mathrm{SP}$, Brazil

Ruvolo-Takasusuki MCC, Del Lama MA (1991) Caracterizaçāo Genética de uma nova esterase de Apis mellifera. 37th Annual Meeting of the Brazilian Genetics Society . Brazil J Genet, Suppl, 14, 111

Ruvolo-Takasusuki MCC, Del Lama MA, Soares AEE (1993) Esterase 7: uma nova região de atividade esterásica em Apis mellifera. 39th Annual Meeting of the Brazilian Genetics Society. Brazil. J. Genetics, Suppl, 16, 323

Tripathi RK, Dixon SE (1968) Hemolymph esterases in the female larval honey bee, Apis mellifera $L$, during caste development. Can J Zool 46, 1013-1017

Val AL, Schwantes AR, Schwantes MLB, Luca PH (1981) Amido hidrolisado de milho como suporte eletroforético. Ciênc e Cult 33, 992-996 